\title{
ASEAN 2020: Một năm nhìn lại trong đại dịch Covid-19
}

\section{ASEAN 2020: A year in review of Covid-19 pademic}

\author{
Dương Văn Huy ${ }^{1 *}$ \\ ${ }^{1}$ Viện Nghiên cứu Đông Nam Á - Viện Hàn lâm Khoa học xã hội Việt Nam, Việt Nam \\ *Tác giả liên hệ, Email: huyiseas@gmail.com
}

THÔNG TIN

DOI: $10.46223 / \mathrm{HCMCOUJS}$. soci.vi.16.2.1779.2021

Ngày nhận: 29/03/2021

Ngày nhận lại: 17/04/2021

Duyệt đăng: 20/04/2021

Tù khóa:

ASEAN; biển Đông; cạnh tranh nước lớn khu vực; đại dịch Covid-19; Đông Nam Á; kinh tế ASEAN

Keywords:

ASEAN; South China Sea; competition between powers in the region; Covid-19 Pandemic; Southeast Asia; ASEAN Economy

\section{TÓM TÁT}

Bài viết phân tích thực trạng đại dịch Covid-19 ở khu vực năm 2020. Tiếp đến, bài viết phân tích những tác động của chúng, trên các chiều kích khác nhau, đối với ASEAN năm 2020. Trong đó, bài viết nhấn mạnh rằng, $\mathrm{ASEAN}$ cũng như toàn thế giới chịu tác động nặng nề của đại dịch Covid-19, tăng trưởng kinh tế các nước suy giảm mạnh mẽ, hoạt động du lịch ngưng trệ, tỷ lệ thất nghiệp tăng. Các kế hoạch phát triển của từng quốc gia cũng như các cam kết của ASEAN bị đảo lộn, hoạt động đầu tư, thương mại và chuỗi cung ứng bị tác động mạnh mẽ. Trong khi đó, năng lực chống chọi với diễn biến phức tạp của đại dịch của nhiều quốc gia trong khu vực còn yếu, sức đề kháng về mặt kinh tế - xã hội ngày càng suy giảm. Tuy nhiên, khu vực ASEAN đang đứng trước những thời cơ phát triển, có điều kiện tham gia sâu hơn vào chuỗi giá trị toàn cầu và thúc đẩy tiến trình số hóa nền kinh tế. Quan trọng là cần có tiếp tục hỗ trợ lẫn nhau giữa các nước để ASEAN để tận dụng cơ hội. Cuối cùng, bài viết khẳng định rằng, ASEAN năm 2020 vừa phải đối diện với những thách thức lớn do tác động của đại dịch Covid-19, đồng thời cũng đón nhận những cơ hội phát triển mới.

\section{ABSTRACT}

The paper analyzes the status quo of the Covid-19 pandemic in the region in 2020. Next, the paper analyzes the effects of the Covid-19 pandemic, with different dimensions, on ASEAN in 2020. Therein, the paper emphasizes that ASEAN like the whole world, is heavily affected by the Covid-19 pandemic, the economic growth of countries has declined strongly, tourism has been the worst affected, the unemployment rate increased due to by Covid-19 pandemic. The development plans of ASEAN countries as well as ASEAN commitments are reversed, investment, trade and supply chain activities are strongly affected. Meanwhile, the capacity of many countries in the region is still weak to cope with the unpredictable development of Covid-19 pandemic. The resilience of the ASEAN countries' socioeconomy is decreasing. However, the region also has the opportunity in order to enhance its development. ASEAN can participate more deeply in the global value chain and accelerate 
the process of digitization of the economy. It is important that countries continue to support each other, this will allow ASEAN to take advantage of this opportunity. Finally, the paper confirms that, ASEAN both faces major challenges due to the impact of the Covid-19 pandemic, and also welcomes new development opportunities in 2020 .

Năm 2020 là năm mà cả thế giới đối diện với thảm họa y tế và kinh tế toàn cầu do đại dịch Covid-19 (do virus corona chủng mới - SARS-CoV-2) gây ra, khiến gần 70 triệu người mắc, gần 1.6 triệu người tử vong (tính đến giữa tháng 12/2020). Đại dịch Covid-19 là thảm kịch của con người. Các biện pháp đưa ra để đối phó với đại dịch có thể cứu sống con người nhưng hệ quả về mặt kinh tế thì rất lớn. Hiện đã có nghiên cứu ước tính tác động kinh tế của virus, trong đó có khu vực Đông Nam Á. Tác động của Covid-19 đang tấn công nền kinh tế ASEAN vào thời điểm mà các nhân tố rủi ro khác, như tốc độ tăng trưởng kinh tế đang giảm trong thời gian vừa qua. Trong ASEAN, dịch bệnh đã làm đình trệ các hoạt động du lịch và đi lại, gây gián đoạn chuỗi cung ứng và nguồn cung lao động. Bất ổn càng gia tăng tâm lý tiêu cực. Những diễn biến này ảnh hưởng tới thương mại, đầu tư, sản xuất và tác động trực tiếp tới tăng trưởng của khu vực. Đồng thời, đại dịch này cũng tác động mạnh mẽ tới tình hình chính trị - an ninh khu vực cũng như các lĩnh vực xã hội khác. Vì vậy không ngạc nhiên khi đa số các vấn đề thảo luận, rà soát về ASEAN và đối tác đều xoay quanh đại dịch.

\section{Thực trạng diễn biến của đại dịch Covid-19 tại Đông Nam Á năm 2020 và phản ứng của ASEAN}

Do khu vực Đông Nam Á nằm ngay cạnh Trung Quốc - nơi bùng phát dịch bệnh Covid19 nên khu vực này sớm cũng đã ghi nhận những ca nhiễm đầu tiên. Và dịch bệnh nhanh chóng lan tràn khắp khu vực. Dịch bệnh này bắt đầu xuất hiện từ tháng 12 năm 2019, với tâm dịch đầu tiên được ghi nhận là thành phố Vũ Hán thuộc tỉnh Hồ Bắc ở miền trung của Trung Quốc, bắt nguồn từ một nhóm người bị mắc bệnh viêm phổi không rõ nguyên nhân, giới chức y tế địa phương xác nhận trước đó nhóm người này đã có tiếp xúc, chủ yếu là với những thương nhân buôn bán và làm việc tại chợ bán buôn hải sản Hoa Nam, nơi bày bán và giết mổ nhiều loài động vật hoang dã và được cho là địa điểm bùng phát dịch bệnh đầu tiên, tuy nhiên, kết luận này hiện vẫn đang còn gây nhiều tranh cãi. Các ca nghi ngờ đầu tiên được báo cáo vào ngày 31 tháng 12 năm 2019, với các triệu chứng đầu tiên xuất hiện khoảng hơn ba tuần trước đó, vào ngày 08 tháng 12 năm 2019. Chợ Hoa Nam đóng cửa vào ngày 01 tháng 01 năm 2020 và những bệnh nhân có triệu chứng được cách $1 y$. Sau đó, những người tiếp xúc gần gũi với người bị nghi ngờ mắc bệnh đã được theo dõi. Ngày 09 tháng 01 năm 2020, ca tử vong do SARS-CoV-2 đầu tiên xảy ra ở Vũ Hán Ngày 11/01/2020, Trung Quốc đã xác nhận ca tử vong đầu tiên ở nhiễm virus ở nước này. Trong khi đó, các ca nhiễm virus đầu tiên được xác nhận bên ngoài Trung Quốc bao gồm hai người phụ nữ ở Thái Lan và một người đàn ông ở Nhật Bản.

Tính đến ngày 25/12/2020, toàn thế giới có 79,729,127 người nhiễm bệnh, và 1,749,340 người tử vong, trong đó Mỹ là quốc gia chịu tác động nặng nền nhất với 19,111,326 ca nhiễm và 337,066 ca tử vong. Tại Đông Nam Á, các quốc gia chịu tác động nặng nề nhất là Indonesia, thứ hai là Philippines, tiếp đến là Myanmar (WHO, 2020). Diễn biến tình hình dịch bệnh ở các quốc gia Đông Nam Á trong năm 2020 có thể xem Hình 1 và Bảng 1 dưới đây: 


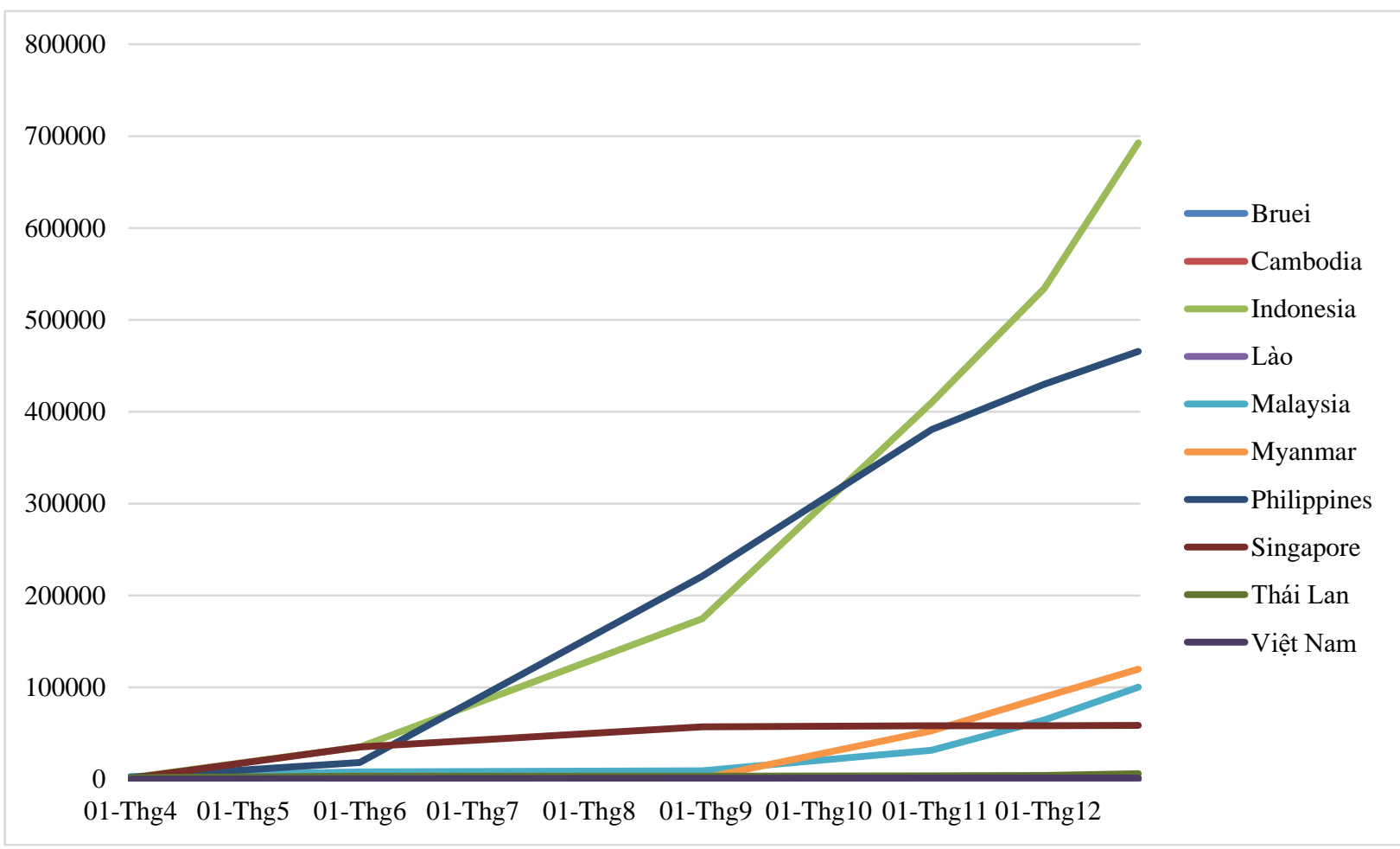

Hình 1. Diễn biến tình hình dịch bệnh Covid-19 tại Đông Nam Á năm 2020

Nguồn: Tác giả xử lý số liệu từ nhiều nguồn khác nhau

\section{Bảng 1}

Diễn biến tình hình đại dịch Covid-19 ở ASEAN năm 2020

\begin{tabular}{lrrrrrrr}
\hline & $\mathbf{0 1 / 0 4}$ & $\mathbf{0 1 / 0 6}$ & $\mathbf{3 1 / 0 7}$ & $\mathbf{0 2 / 1 0}$ & $\mathbf{3 1 / 1 0}$ & $\mathbf{3 0 / 1 1}$ & $\mathbf{2 5 / 1 2}$ \\
\hline Bruei & 129 & 141 & 141 & 146 & 148 & 150 & 152 \\
Cambodia & 109 & 125 & 234 & 287 & 291 & 323 & 363 \\
Indonesia & 1,551 & 34,884 & 106,336 & 291,182 & 410,088 & 534,266 & 692,838 \\
Lào & 09 & 19 & 20 & 23 & 24 & 39 & 41 \\
Malaysia & 2,766 & 7,819 & 8,964 & 11,484 & 31,548 & 64,485 & 100,318 \\
Myanmar & 14 & 224 & 353 & 14,383 & 52,706 & 89,486 & 119,788 \\
Philippines & 2,084 & 18,086 & 89,374 & 314,079 & 380,729 & 429,864 & 465,724 \\
Singapore & 926 & 34,884 & 51,809 & 57,784 & 58,015 & 58,213 & 58,495 \\
Thái Lan & 1,651 & 3,081 & 3,310 & 3,575 & 3,780 & 3,998 & 5,829 \\
Việt Nam & 212 & 328 & 509 & 1,095 & 1,180 & 1,343 & 1,432 \\
\hline
\end{tabular}

Nguồn: Tác giả tổng hợp từ các nguồn khác nhau

Có thể thấy, Covid-19 đã bùng phát ở hầu hết các quốc gia Đông Nam Á, trong đó một số quốc gia chịu ảnh hưởng nặng nề nhất như Philippines, Indonesia và Singapore. Các quốc gia khác số ca nhiễm ở mức độ khác nhau nhưng đều chịu tác động nặng nề bởi đại dịch.

Đối với Indonesia, ngày $02 / 03 / 2020$ xác nhận 02 công dân đầu tiên của nước này đã dương tính với SARS-CoV-2. Indonesia cho biết, 02 ca bệnh mới là một phụ nữ 64 tuổi cùng với 
con gái bà, 31 tuổi. Cả 02 đã nhận kết quả dương tính sau khi tiếp xúc với một công dân Nhật Bản sống tại Malaysia. Công dân Nhật này đã nhận kết quả dương tính với virus sau khi quay trở về từ Indonesia. Đồng thời, ca tử vong đầu tiên được ghi nhận tại nước này vào ngày 11/03/2020, bệnh nhân là nữ, 53 tuổi, quốc tịch nước ngoài, được xác nhận là trường hợp thứ 25 dương tính với SARS-CoV-2 ở Indonesia. Đến ngày $01 / 04 / 2020$, nước này có 1,551 ca nhiễm và 136 ca tử vong, con số này tăng lên 34,884 ca nhiễm và 1,613 ca tử vong tính đến ngày 01/06/2020. Đến ngày 25/12/2020, Indonesia đứng đầu ở khu vực về số ca nhiễm với 692,838 ca và 20,589 ca tử vong. Chính quyền Tổng thống Jokowi cũng đã thực thi nhiều chính sách quyết liệt nhằm hạn chế sự lây lan của đại dịch, song đến nay sự lây lan đại dịch ở nước này vẫn diễn biến rất phức tạp.

Đối với Philippines, nước này ghi nhận ca nhiễm SARS-CoV-2 đầu tiên vào ngày 30/01/2020. Ngày 02/02, Bộ Y tế Philippines công bố người chết đầu tiên tại nước này và là trường hợp tử vong đầu tiên vì SARS-CoV-2 xuất hiện ngoài Trung Quốc, đó là một công dân Trung Quốc 44 tuổi. Ngày 11/03/2020, Philippines xác nhận công dân đầu tiên của nước này qua đời vì dịch Covid-19. Bệnh nhân nói trên là người Philippines đầu tiên chết vì Covid-19 tại nước này. Đến ngày $01 / 04 / 2020$, nước này có 2,084 ca nhiễm và 88 ca tử vong. Đến ngày $31 / 08 / 2020$, con số ca nhiễm lên tới 220,819 và 3,558 ca tử vong. Bệnh dịch đã nhanh chóng lan nhanh ở nước này, tính đến ngày 25/12/2020, Philippines là nước đứng thứ hai ở khu vực về số ca nhiễm với con số lên tới 465,724 ca và 9,055 ca tử vong. Mặc dù chính phủ Philippines từ sớm đã thực hiện các biện pháp quyết liệt nhằm ngăn chặn đà lây lan của đại dịch, và thực hiện nhiều biện pháp khắc phục hậu quả của đại dịch gây ra. Song cho đến nay, đại dịch vẫn lây lan nhanh và diễn biến phức tạp ở quốc gia này.

Trong khi đó, Myanmar, ngày 23/03/2020, nước này chính thức thông báo phát hiện hai ca nhiễm SARS-CoV-2 đầu tiên, đều từ phương Tây nhập vào. Đó là hai công dân Miến Điện từ Anh và từ Mỹ về nước. Ngày 31/03/2020, Myanmar xác nhận ca Covid-19 tử vong đầu tiên, hơn một tuần sau khi nước này xác nhận ca nhiễm đầu tiên. Đến ngày 01/04/2020, Myanmar có 14 ca nhiễm, con số này tăng lên 14,383 và 321 ca tử vong vào ngày $02 / 10$, sau đó tăng mạnh lên 52,706 ca nhiễm và 1,237 ca tử vong tính đến ngày $31 / 10$. Tính đến ngày $10 / 08 / 2020$, Myanmar có 360 ca nhiễm và 06 ca tử vong. Đến ngày 25/12/2020, Myanmar lên tới 119,788 ca nhiễm và 2,532 ca tử vong. Với con số này, Myanmar là quốc gia đứng thứ ba ở khu vực Đông Nam Á về số ca nhiễm và ca tử vong do Covid-19.

Trong khi đó, tại Malaysia, ca nhiễm Covid-19 đầu tiên tại quốc gia này vào ngày 24/01/2020. Đến ngày 17/03/2020, Malaysia thông báo 02 ca tử vong đầu tiên do bệnh Covid19. Đến ngày 10/08/2020, nước này có 9,094 ca nhiễm và 125 ca tử vong. Đến ngày $25 / 12 / 2020$, Malaysia đứng thứ tư ở khu vực về số ca nhiễm với con số 100,318 ca và 446 ca tử vong. Đối với Singapore, với tư cách là quốc gia có mức độ di chuyển con người hàng đầu ở khu vực, Singapore đỡ ghi nhận ca nhiễm SARS-CoV-2 đầu tiên tại nước này vào ngày 23/01/2020. Ngày 21/03/2020, Singapore có 02 ca tử vong đầu tiên vì các biến chứng do mắc virus Corona mới (SARS-CoV-2) gây ra bệnh Covid-19. Bệnh nhân đầu tiên là một công dân Singapore, 75 tuổi. Tính đến ngày 10/08/2020, nước này có 55,292 ca nhiễm và 27 ca tử vong. Đến ngày 25/12/2020, Singapore đứng thứ năm ở khu vực với 58,495 ca nhiễm và 29 ca tử vong.

Còn tại Thái Lan, nước này là quốc gia đầu tiên ở Đông Nam Á xuất hiện nhiễm SARSCoV-2, cũng là ca nhiễm virus đầu tiên ngoài lãnh thổ Trung Quốc. Ngày 13/01/2020 thông báo bệnh nhân mắc viêm phổi lạ là một nữ du khách 61 tuổi đến từ thành phố Vũ Hán (Trung Quốc). Các bác sĩ ban đầu chẩn đoán nữ du khách Trung Quốc trên bị viêm phổi nhẹ vào ngày 08/01/2020. Ngày 01/03/2020, giới chức Thái Lan thông báo ca tử vong đầu tiên ở nước này do dịch viêm đường hô hấp cấp Covid-19. Tính đến ngày 10/08/2020, nước này có $3,351 \mathrm{ca}$ 
nhiễm và 58 ca tử vong. Tính đến ngày $25 / 12 / 2020$, Thái Lan có 5,829 ca nhiếm và 60 ca tử vong.

Đối với Việt Nam, ca nhiễm đầu tiên được xác nhận tại Việt Nam vào ngày 23/01/2020, các ca nhiễm được xác nhận từ bệnh nhân có lịch sử di chuyển qua Trung Quốc. Sau một thời gian dài Việt Nam không có ca tử vong thì đến ngày 31/07/2020 Việt Nam ghi nhận ca tử vong đầu tiên liên quan đến Covid-19, đó là bệnh nhân 428 là nam, 70 tuổi, có địa chỉ thường trú tại thành phố Hội An, tỉnh Quảng Nam, là bệnh nhân tại khoa Nội thận - Nội tiết, Bệnh viện Đà Nẵng. Tính đến ngày 10/08/2020, Việt Nam có 842 ca nhiễm với 13 người tử vong. Đến ngày $25 / 12 / 2020$, Việt Nam có 1,432 ca nhiếm và 35 ca tử vong.

Đối với Campuchia, ngày 07/03/2020, Campuchia đã ghi nhận trường hợp người Campuchia đầu tiên nhiễm virus corona là một người đàn ông 38 tuổi. Trước đó, ngày 17/01/2020, Campuchia đã ghi nhận một ca nhiễm virus corona chủng mới, nhưng bệnh nhân là người Trung Quốc, người này đã hồi phục và về nhà. Cho đến ngày 10/08/2020, nước này ghi nhận 251 ca nhiễm, ngày 25/12/2020 có 363 ca nhiễm và chưa có ca tử vong nào. Bên cạnh đó, Brunei, nghi nhận ca nhiễm Covid-19 đầu tiên ngày 09/03/2020. Theo cơ quan này, một người đàn ông bản địa, 53 tuổi đã có kết quả xét nghiệm dương tính với virus SARS-CoV-2 sau khi trở về nước từ Kuala Lumpur, Malaysia ngày 03/03/2020 cùng với 03 người bạn khác. Ngày 28/03/2020, chính quyền Brunei đã công bố về ca đầu tiên tử vong do bệnh Covid-19. Trường hợp tử vong là một người đàn ông 64 tuổi, bị mắc bệnh sau khi trở về từ Malaysia và Campuchia. Đến ngày 10/08/2020, nước này ghi nhận 142 ca nhiễm, đến ngày 25/12/2020 có 152 ca nhiễm và 03 ca tử vong. Đối với Lào là quốc gia cuối cùng ở Đông Nam Á ghi nhận có bệnh nhân nhiễm Covid-19 vào ngày 24/03/2020. Đến ngày 25/08/2020, nước này ghi nhận 20 ca nhiễm, đến ngày 10/12/2020, có 41 và cũng chưa có ca tử vong nào. Đồng thời, Đông Timor (Timor Leste), nước này xác nhận bệnh nhân Covid-19 đầu tiên ngày 21/03/2020, là một người trở về từ nước ngoài. Đến ngày 10/8/2020 nước này có 25 ca nhiễm, đến ngày $25 / 12 / 2020$, có 41 ca nhiễm và chưa có ca tử vong nào.

Phản ứng của ASEAN: Đại dịch Covid-19 đã tác động tiêu cực tới nền kinh tế và sự ổn định tài chính khu vực ASEAN, là yếu tố dẫn tới tăng trưởng âm của ASEAN trong năm 2020. Những gián đoạn do đại dịch gây ra đã cho thấy tầm quan trọng của việc đảm bảo khả năng chống chịu của nền kinh tế khu vực của chúng ta trước các cú sốc.

Ngay từ khi đại dịch lan truyền đến ASEAN, khối này này dưới sự dẫn dắt của quốc qua chủ tịch là Việt Nam đã sớm có những biện pháp ứng phó quyết liệt. Trước diễn biến phức tạp của dịch bệnh viêm đường hô hấp cấp do chủng mới của virus Corona (Covid-19) gây ra, ASEAN đã có những biện pháp hợp tác nhanh chóng và kịp thời đề góp phần ngăn chặn sự lây lan của đại dịch và hợp tác giải quyết những thách thức do đại dịch gây ra. Kể từ cuối tháng 01/2020, các ngành quốc phòng, đối ngoại và y tế của ASEAN đã cam kết phối hợp với nhau để đối phó với đại dịch Covid-19. Tuy nhiên, ban đầu các quốc gia ASEAN cũng có những đánh giá khác nhau đối với mức độ rủi ro của Covid-19 và cũng có những biện pháp ứng phó ban đầu khác nhau.

Ngày 09/04/2020, Bộ trưởng Ngoại giao các nước thành viên ASEAN đã nhất trí thành lập một quỹ ứng phó với dịch viêm đường hô hấp cấp Covid-19 để cùng nhau chống lại dịch bệnh nguy hiểm này. Theo tuyên bố được đưa ra sau hội nghị trực tuyến của Hội đồng điều phối ASEAN lần thứ 25 về Covid-19, các ngoại trưởng đã nhất trí thành lập Quỹ ứng phó với Covid19 của ASEAN. Việt Nam với tư cách là Chủ tịch ASEAN năm 2020 đã chủ trì Hội nghị Cấp cao đặc biệt ASEAN và Hội nghị Cấp cao đặc biệt ASEAN+3 về ứng phó dịch bệnh Covid-19, dưới hình thức họp trực tuyến ngày 14/04/2020. Sau khi trao đổi với các nước thành viên ASEAN, trong vai trò Chủ tịch ASEAN 2020, Thủ tướng Chính phủ Việt Nam Nguyễn Xuân 
Phúc ngày 14/04/2020 đã ra Tuyên bố của Chủ tịch ASEAN về Úng phó chung của ASEAN trước bùng phát của dịch bệnh. Đồng thời, các quốc gia $\mathrm{ASEAN}+3$ cũng đã có Tuyên bố chung Hội nghị Cấp cao đặc biệt $\mathrm{ASEAN+3}$ về ứng phó dịch bệnh Covid-19. Bản thân nước Chủ tịch ASEAN năm nay cũng đã có những hoạt độ hô̂ trợ nhiều quốc gia thành và cũng đã chia sẻ nhiều kinh nghiệm quý báu của mình cho các nước khác tham khảo để chống lại đại dịch.

Bên cạnh đó, nhiều sáng kiến của ASEAN về hợp tác ứng phó Covid-19 và các nguy cơ dịch bệnh được công bố và đưa vào triển khai, như Quỹ ASEAN ứng phó Covid-19 (CARF), Kho dự phòng vật tư y tế khẩn cấp khu vực (RRMS), Khung chiến lược ứng phó các tình huống $\mathrm{y}$ tế khẩn cấp của ASEAN và Trung tâm $\mathrm{Y}$ tế ASEAN ứng phó với các tình huống y tế công cộng khẩn cấp và dịch bệnh mới nổi. Lãnh đạo ASEAN cũng thông qua Khung phục hồi tổng thể ASEAN và Kế hoạch triển khai đồng bộ trên cả ba trụ cột Cộng đồng nhằm hỗ trợ người dân và doanh nghiệp sớm khắc phục hậu quả dịch bệnh, ổn định đời sống kinh tế-xã hội ở các quốc gia.

Ngoài ra, ASEAN đang nghiên cứu các Quy trình vận hành tiêu chuẩn $(\mathrm{SOP})$ đối với các trường hợp khẩn cấp về sức khoẻ cộng động. Tháng 11/2020, các nhà lãnh đạo ASEAN đã ra tuyên bố về việc xây dựng một khuôn khổ hành lang đi lại trong ASEAN. Mặc dù vậy, việc đẩy mạnh du lịch toàn khu vực ASEAN khó khả thi trong giai đoạn trước mắt, do tình hình đại dịch ở các nước thành viên đang ở giai đoạn và mức độ khác nhau. Các nhà lãnh đạo ASEAN cũng đã thông qua Khung phục hồi tổng thể ASEAN và Kế hoạch thực hiện; các kết quả và mục tiêu sẽ được các ngành liên quan của ASEAn tiếp tục xác định rõ.

Mặt khác, ASEAN cũng đẩy mạnh hợp tác với các đối tác của mình trong việc tìm kiếm sự hợp tác và hỗ trợ trong việc ứng phó với đại dịch Covid-19 và thúc đẩy sự phùi hồi về mặt kinh tế. Chẳng hạn Mỹ đã hỗ trợ 87 triệu USD, Nhật Bản hỗ trợ hơn 01 triệu USD, Trung Quốc hỗ trợ hơn 01 triệu USD và Liên minh châu Âu (EU) hỗ trợ 800 triệu euro. Ngoài những hành động thiết thực này, thông điệp chính trị từ những cam kết của các nước đối tác cũng quan trọng không kém - đó là giữ vững tinh thần chủ nghĩa đa phương và duy trì một trật tự khu vực cởi mở và bao trùm.

\section{Tác động của đại dịch Covid-19 đối với ASEAN}

Thứ nhất, tác động đối với kinh tế - xã hội Đông Nam A. Đại dịch Covid-19 ảnh hưởng sâu rộng tới các nền kinh tế ASEAN trong bối cảnh tăng trưởng toàn cầu chững lại, kinh tế thế giới đang có chiều hướng đi xuống. Cụ thể như sau:

Một là, tác động đến tăng trương kinh tế của các quốc gia Đông Nam Á. Các nền kinh tế Đông Nam Á đang bị ảnh hưởng lớn trong cuộc khủng hoảng kinh tế toàn cầu do đại dịch lan rộng. Tác động kinh tế sẽ rất lớn, ngang bằng với cuộc khủng hoảng tài chính Châu Á 19971998, hoặc có lẽ lớn hơn nhiều. Một mặt, các nền kinh tế của ASEAN đã chuẩn bị tốt hơn so với cuộc khủng hoảng tài chính Châu Á xảy ra ở khu vực này hơn hai thập kỷ trước, với dự trữ ngoại hối lớn hơn và vị thế kinh tế vĩ mô tốt hơn so với tình hình của họ trong cuối những năm 1990. Tuy nhiên, cú sốc kinh tế từ Covid-19 có thể sâu hơn và kéo dài hơn tùy thuộc vào cách thức đại dịch xảy ra, và có sự không chắc chắn lớn xung quanh sự lây lan và ngăn chặn cuối cùng của virus (Searight, 2020).

Đối với tăng trưởng của kinh tế Đông Nam Á/ASEAN sụt giảm một cách nghiêm trọng, theo như dự báo của Ngân hàng Phát triển Á Châu (ADB) vào tháng 09/2020, đa phần các quốc gia ASEAN tăng trưởng âm, chỉ có Brunei, Myanmar và Việt Nam là tăng trưởng dương. Trong đó, các quốc gia tăng trưởng âm lớn như Thái Lan (-8\%), Philippines (-7.3\%), Singapore ($6.2 \%)$, Malaysia $(-5 \%)$, Cambodia $(-4 \%)$, Lào $(-2.5 \%)$, và Indonesia $(-1 \%)$. Còn các quốc gia tiếp tục là điểm sáng kinh tế của khu vực như Myanmar $(1.8 \%)$, Việt Nam $(1.8 \%)$ và Brunei (1.4\%). Đến năm 2021, dự báo kinh tế các quốc gia ASEAN có sự tăng trưởng khả quan hơn, cụ 
thể xem Hình 2 dưới đây:

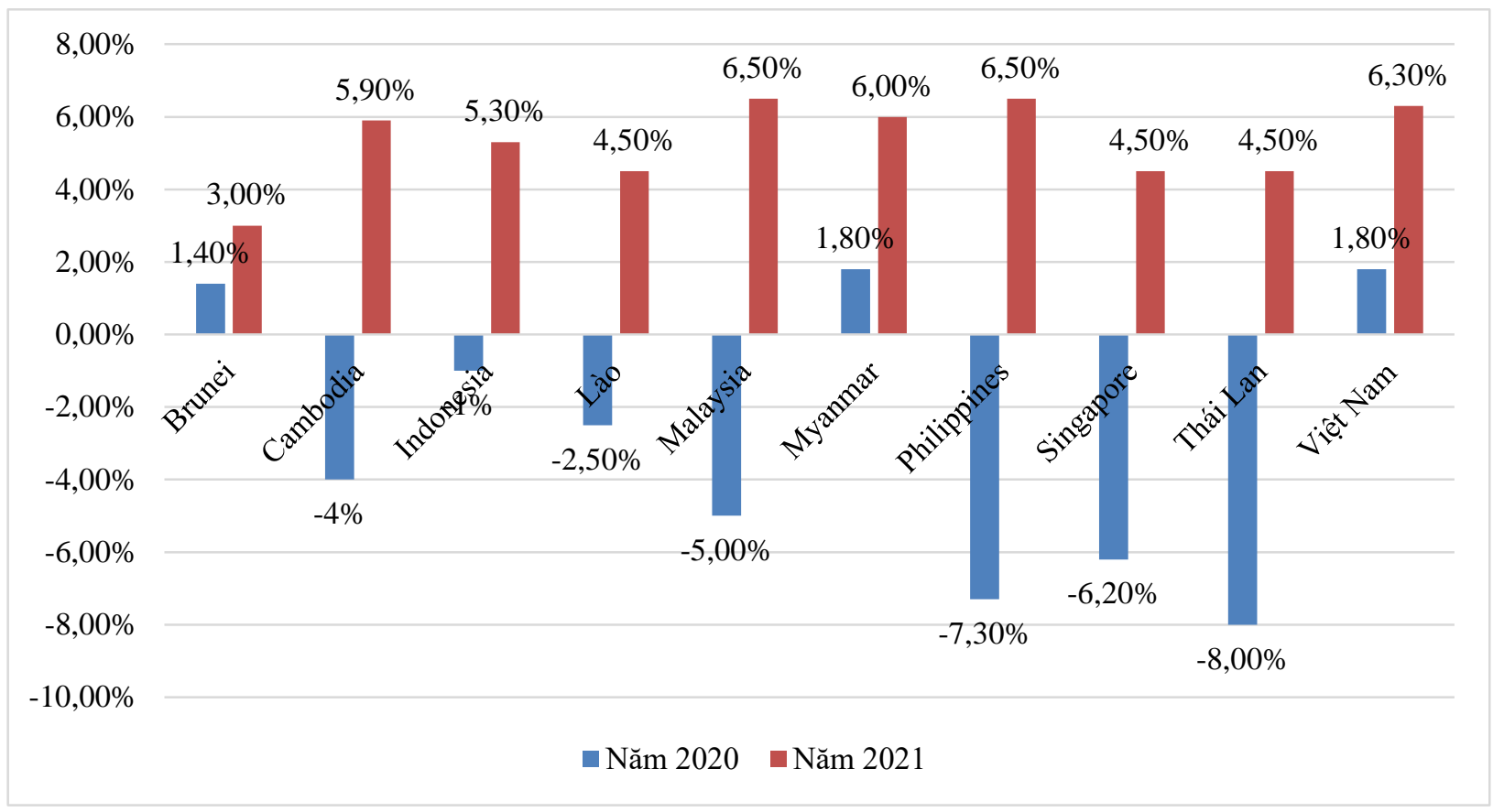

Hình 2. Dự báo tăng trưởng kinh tế của các quốc gia ASEAN năm 2020 và năm 2021

Nguồn: Số liệu tính toán từ $\mathrm{ADB}$ (2020)

Tuy nhiên, về lâu dài, rất khó để dự đoán tác động kinh tế cuối cùng đối với Đông Nam Á bởi vì có sự không chắc chắn lớn về việc đại dịch sẽ diễn ra như thế nào trong thời gian tới, và cuộc khủng hoảng sẽ định hình lại nền kinh tế toàn cầu như thế nào. ASEAN có khả năng tăng cường quá trình tiếp tục tăng cường năng lực để tiếp nhận sự dịch chuyển kinh tế từ Trung Quốc và các nước Đông Á sang Đông Nam Á hay không, mặc dù một số lĩnh vực nhất định ở một số nền kinh tế Đông Nam Á đã được hưởng lợi từ sự dịch chuyển chuỗi cung ứng gần đây khỏi Trung Quốc, và điều này có vẻ sự dịch chuyển này sẽ thuận lợi hơn sau đại dịch. Về mặt sáng sủa hơn, việc chuyển hoạt động kinh tế sang điện toán đám mây và nhu cầu truy tìm dấu vết di động và các giải pháp công nghệ khác để ngăn chặn và ứng phó với sự bùng phát của virus trong tương lai có thể mang lại lợi ích cho Đông Nam Á, đặc biệt là các quốc gia như Singapore, Indonesia và Việt Nam, những quốc gia đã ở trên đỉnh cao của nền kinh tế kỹ thuật số dựa trên ứng dụng di động. Nếu chúng ta có cái nhìn khác về cuộc khủng hoảng Covid-19 lần này cho thấy, sự thay đổi toàn cầu hoặc khu vực về nhu cầu đối với các ứng dụng kỹ thuật số và các chính sách của chính phủ được thiết kế để hỗ trợ lĩnh vực này, có thể thúc đẩy sự đổi mới và thúc đẩy các doanh nhân làm việc trong nền kinh tế kỹ thuật số, điều này sẽ làm tăng triển vọng tăng trưởng và phát triển cho các nền kinh tế Đông Nam Á (Searight, 2020).

Hai là, đại dịch Covid-19 làm gián đoạn du lịch, sụ đi lại, chuỗi cung úng và cung úng về lao động. Các nước ASEAN rất cởi mở đối với thương mại và đầu tư cũng như du lịch, tất cả đều bị phá vỡ nghiêm trọng bởi đại dịch toàn cầu đang lan rộng. Sự bất ổn của đại dịch hiện nay đang thức đẩy tâm lý tiêu cực gia tăng. Tất cả điều này ảnh hưởng đến thương mại, đầu tư và đầu ra của sản xuất và dịch vụ, nó ảnh hưởng mạnh mẽ đến tăng trưởng kinh tế. Du lịch và cách hoạt động kinh doanh lữ hành cũng như các ngành công nghiệp liên quan, đặc biệt là các hãng hàng không và khách sạn, là những nhân tố đầu tiên bị ảnh hưởng. Tình hình sẽ trở nên tồi tệ hơn khi các quốc gia thực hiện đóng cửa đất nước.

Trong ASEAN, có thể thấy rõ, du lịch cũng như những ngành công nghiệp liên quan, đặc 
biệt là hàng không và khách sạn, là những đối tượng chịu nhiều ảnh hưởng nhất. Mọi chuyện càng trở nên tồi tệ khi nhiều quốc gia trong khu vực quyết định ra lệnh phong tỏa hoặc đóng cửa đất nước.

Sự gán đoạn nguồn cung nguyên liệu từ Trung Quốc cũng ảnh hưởng trực tiếp đến chuỗi giá trị và sản xuất trong $\mathrm{ASEAN}$. Trung Quốc là đầu mối khu vực, vì vậy sự gián đoạn chuỗi cung ứng, dù chỉ trong ngắn hạn, cũng gây ảnh hưởng nghiêm trọng tới toàn bộ hệ thống. Sự gián đoạn nguồn cung chủ yếu từ Trung Quốc sẽ tác động đến chuỗi giá trị và làm gián đoạn sản xuất. Vì Trung Quốc là trung tâm của khu vực và chiến $12 \%$ thương mại toàn cầu, do đó chi phí cho gián đoạn trong ngắn hạn sẽ tăng cao.

Tác động tiêu cực của việc sắp xếp cách ly kiểm dịch đối với nguồn cung lao động cũng bị ảnh hưởng tuỳ theo thời gian và lĩnh vực. Sản xuất đã bị ảnh hưởng nặng nề hơn so với các ngành công nghiệp dịch vụ, trong đó viễn thông và sự các hỗ trợ công nghệ khác hạn chế sự sụt giảm về năng suất. Tất cả những gián đoạn này sẽ dẫn đến sự sụt giảm mạnh mẽ về nhu cầu trong nước.

Chi phí kinh tế cao nhất có thể đến từ các yếu tố vô hình. Tác động của tâm lý tiêu cực về tăng trưởng kinh tế và sự không chắc chắn nói chung ảnh hưởng đến thị trường tài chính, điều này sẽ giảm đầu tư, tiêu dùng và tăng trưởng trong dài hạn. Suy thoái kinh tế trên khắp thế giới dường như không thể tránh khỏi, mặc dù các biện pháp kích thích đã được dự tinihs. Nếu vậy, sẽ có sự tăng tăng mạnh mẽ về thất nghiệp, nghèo đói. Một số mức độ tách rời khỏi Trung Quốc, hoặc sự mất cân bằng (de-globalisation) nói chung, cũng có thể là dấu hiệu cho thấy từ đại dịch này (Menon, 2020).

Bên cạnh đó, đối với các quốc gia Đông Nam Á, thì Singapore, Malaysia và Thái Lan hội nhập mạnh mẽ hơn vào chuỗi cung ứng toàn cầu và sẽ bị ảnh hưởng mạnh nhất do sự suy giảm nhu cầu đối với hàng hoá được sản xuất trong đó. Còn Indonesia và Philippines đã tăng cường hội nhập chuỗi cung ứng và cũng sẽ không thể "miễn dịch" (Immune). Việt Nam là thành viên của ASEAN mới duy nhất hội nhập vào chuỗi cung ứng với Trung Quốc và cũng đã bị gián đoạn nghiêm trọng về nguồn cung. Theo thời gian, các điều chỉnh về nguồn cung sẽ thay đổi mô hình thương mại và đầu tư. Những điều chỉnh căn bản đòi hỏi phải tái phân bổ các hoạt động trong chuỗi cung ứng từ Trung Quốc sang các nước ASEAN (Menon, 2020).

Ba là, tác động đến hoạt động thương mại và đầu tu ở Đông Nam Á. Đại dịch Covid-19 là sụt giảm các hoạt động thương mại nội khối ASEAN và với các đối tác bên ngoài. Thương mại hàng hoá của ASEAN sẽ sụt giảm mạnh mẽ. Các nền kinh tế ASEAN có một loạt các đối tác thương mại và đầu tư đa dạng, bao gồm Mỹ, Liên minh Châu Âu (EU), Trung Quốc và thương mại nội khối ASEAN.

Mặt khác, nhu cầu trong nước giảm mạnh do chính sách đóng cửa đất nước và các biện pháp y tế công cộng khác sẽ có tác động nhân lên lớn đối với các nền kinh tế này, vì tiêu dùng chiếm khoảng $60 \%$ GDP ở các nền kinh tế lớn của ASEAN, với Singapore là một ngoại lệ.

Bên cạnh đó, trong lĩnh vực đầu tư trực tiếp nước ngoài (FDI), tác động từ dịch bệnh Covid-19 đến ASEAN khi dòng vốn FDI bị rút khỏi khu vực này. Trong khi FDI nói chung đang khó khăn, các nhà đầu tư quốc tế vào thị trường chứng khoán và trái phiếu mới nổi với khu vực đã thúc đẩy dòng vốn lớn chảy ra khỏi khu vực để họ tìm kiếm nơi an toàn trước đại dịch toàn cầu ngày càng sâu rộng. Theo Viện nghiên ứu Tài chính Quốc tế, dòng vốn chảy ra từ các thị trường mới nổi đã lên tới gần 100 tỷ USD trong năm nay, với các nền kinh tế Đông Nam Á đang phải đối diện với sự tác động lớn. Indonesia đã chứng kiến một dòng vốn đầu tư trị giá 8.2 tỷ USD chảy ra khỏi nước này vào cuối tháng 03 . Những dòng tiền này đã dẫn đến sự mất giá tiền tệ trong khu vực, đặc biệt là đồng rupiah của Indonesia, vốn đã mất giá $14.5 \%$ từ đầu năm năm 
2020, trong khi đồng baht của Thái Lan, đồng ringgit của Malaysia và đồng đô la Singapore đều mất giá hơn $4 \%$ trong giai đoạn từ ngày 02 - 19/03/2020. Các ngân hàng trung ương trong khu vực cũng đã can thiệp để hỗ trợ tiền tệ của họ, nhằm hỗ trợ và nâng đỡ nền kinh tế của họ trước cuộc khủng hoảng Covid-19. (Searight, 2020) Đầu tư nước ngoài suy giảm một cách rõ rệt đối với các quốc gia ASEAN, xem Bảng 2 và Bảng 3 dưới đây:

\section{Bảng 2}

Đầu tư trực tiếp nước ngoài (so sánh cùng kỳ của năm, tỷ lệ \%)

\begin{tabular}{llllllc}
\hline & $\begin{array}{l}\text { Quý } \\
\mathbf{1 / 2 0 1 9}\end{array}$ & $\begin{array}{l}\text { Quý } \\
\mathbf{2 / 2 0 1 9}\end{array}$ & $\begin{array}{l}\text { Quý } \\
\mathbf{3 / 2 0 1 9}\end{array}$ & $\begin{array}{l}\text { Quý } \\
\mathbf{4 / 2 0 1 9}\end{array}$ & $\begin{array}{l}\text { Quý } \\
\mathbf{1 / 2 0 2 0}\end{array}$ & $\begin{array}{l}\text { Quý } \\
\mathbf{2 / 2 0 2 0}\end{array}$ \\
\hline Brunei & -92.80 & 130.92 & 2.13 & 7.10 & 2.39 & - \\
Cambodia & 7.05 & 7.05 & 7.05 & 7.05 & - & - \\
Indonesia & 5,07 & 5.05 & 5.02 & 4.97 & 2.97 & -5.32 \\
Lào & - & - & - & - & - & - \\
Malaysia & 4.54 & 4.78 & 4.40 & 3.55 & 0.73 & -17.07 \\
Myanmar & 6.75 & 6.75 & 6.75 & - & - & - \\
Philippines & 5.74 & 5.39 & 6.34 & 6.66 & -0.71 & -16.48 \\
Singapore & 1.00 & 0.20 & 0.70 & 1.00 & -0.30 & -13.20 \\
Thái Lan & 2.89 & 2.44 & 2.63 & 1.49 & -1.97 & -12.16 \\
Việt Nam & 6.82 & 6.73 & 7.48 & 6.97 & 3.68 & 0.36 \\
\hline
\end{tabular}

Nguồn: Lee, Negara, và Sambodo (2020)

\section{Bảng 3}

Đầu tư trực tiếp nước ngoài tại các quốc gia ASEAN (triệu USD)

\begin{tabular}{lllllll}
\hline & $\begin{array}{l}\text { Quý } \\
\mathbf{1 / 2 0 1 9}\end{array}$ & $\begin{array}{l}\text { Quý } \\
\mathbf{2 / 2 0 1 9}\end{array}$ & $\begin{array}{l}\text { Quý } \\
\mathbf{3 / 2 0 1 9}\end{array}$ & $\begin{array}{l}\text { Quý } \\
\mathbf{4 / 2 0 1 9}\end{array}$ & $\begin{array}{l}\text { Quý } \\
\mathbf{1 / 2 0 2 0}\end{array}$ & $\begin{array}{l}\text { Quý } \\
\mathbf{2 / 2 0 2 0}\end{array}$ \\
\hline Brunei & 24 & 92 & 192 & 66 & - & - \\
Cambodia & 920 & 937 & 900 & 912 & 958 & - \\
Indonesia & 6,794 & 7,573 & 5,970 & 4,610 & 4,729 & 4,065 \\
Lào & 169 & 114 & 103 & 171 & 369 & 171 \\
Malaysia & 5,471 & 638 & 592 & 2,403 & 1,236 & 38 \\
Myanmar & 508 & 549 & 728 & 507 & - & - \\
Philippines & 1,945 & 1,697 & 1,564 & 2,442 & 1,669 & - \\
Singapore & 24,639 & 26,701 & 26,406 & 27,731 & 14,833 & 18,197 \\
Thái Lan & 669 & 2,076 & 4,425 & $-1,040$ & 3,642 & 1,202 \\
Việt Nam & 3,220 & 3,970 & 4,080 & 4,850 & 3,020 & - \\
\hline
\end{tabular}


Nguồn: Lee và cộng sự (2020)

Bốn là, đại dịch Covid-19 tác động đến lao động việc làm tại khu vục. Hầu hết quốc gia hiện đang trải qua thời kỳ khó khăn do cả thế giới phải đối mặt với đại dịch Covid-19. Các biện pháp phong tỏa và giãn cách xã hội đang được áp dụng khiến "cuộc khủng hoảng y tế toàn cầu" đang nhanh chóng trở thành "cuộc khủng hoảng kinh tế xã hội toàn cầu," trong đó có khu vực Đông Nam Á. Trước sự lan tràn của đại dịch, nhiều quốc gia trong khu vực đã phải thực hiện chính sách phong toả đất nước ở những cấp độ khác nhau, nhiều nhà máy phải đóng cửa, nhiều doanh nghiệp phá sản hoặc hoạt động cầm chừng. Hoạt động đầu tư nước ngoài giảm. Điều này đẩy hàng triệu lao động ở Đông Nam Á rơi vào cảnh thất nghiệp hoặc thiếu việc làm khi các hoạt động kinh tế phải đột ngột dừng lại. Theo Báo cáo của Ưy ban Kinh tế và Xã hội khu vực Châu Á-Thái Bình Dương Liên hợp quốc (ESCAP) ban hành ngày 26/03/2020 cho biết, hàng triệu lao động ở Đông Nam Á có thể bị mất việc làm khi các hoạt động kinh tế phải đột ngột dừng lại, do chính phủ các nước trong khu vực tăng cường các nỗ lực nhằm kiềm chế sự lây lan của dịch bệnh viêm đường hô hấp cấp Covid-19. ESCAP cho rằng trong khi chưa có dữ liệu chính xác về tác động của đại dịch Covid-19 đối với lĩnh vực tuyển dụng, nhưng ảnh hưởng sẽ rất lớn bởi lĩnh vực dịch vụ và chế tạo sản xuất cần nhiều lao động tạo nên $80 \%$ khu vực phi chính thức và các doanh nghiệp nhỏ và vừa (SME) (VNA, 2020).

Năm là, sụ tác động mang tính đặc thù đối với tùng quốc gia. Đại dịch Covid-19 ảnh hưởng bao trùm lên nền kinh tế ASEAN, tuy vậy ở mỗi quốc gia thành viên lại có những tác động mang tính đặc thù. Kinh tế nhiều nước ASEAN phụ thuộc ngành du lịch, trong đó Thái Lan là quốc gia phụ thuộc vào ngành du lịch nhiều nhất. Việc đình chỉ và có khả năng phục hồi du lịch rất chậm sẽ ảnh hưởng nặng nề đến nền kinh tế Thái Lan, điều này phụ thuộc vào chi tiêu du lịch và du lịch cho một phần năm GDP của nước này, và cũng sẽ tác động đến các nền kinh tế phụ thuộc vào du lịch của Malaysia, Indonesia, Philippines và Việt Nam. Singapore đã bị ảnh hưởng bởi khối lượng thương mại giảm vào giữa cuộc chiến tranh thương mại giữa Mỹ và Trung Quốc năm 2019 và hiện đang phải đối mặt với sự sụt giảm thêm về thương mại hàng hóa cũng như thương mại dịch vụ và du lịch giảm. Hơn nữa, tăng trưởng sụt giảm tại Trung Quốc ảnh hưởng nhiều tới Lào và Campuchia do hai quốc gia này có nguồn đầu tư lớn từ Trung Quốc. Philippines có dân số lao động ở nước ngoài lớn, do vậy, lệnh hạn chế di chuyển sẽ ảnh hưởng đến dòng lưu chuyển lao động của nước này. Cuộc chiến giá cả do dịch bệnh đang gián tiếp gây ra tác động mạnh đến Brunei và Malaysia, hai nước xuất khẩu dầu.

Thứ hai, tác động về mặt xã hội đối với Đông Nam A. Sụ bùng phát của đại dịch Covid-19 ở khu vục này đã và đang tác động đến bộ phận dễ bị tổn thuơng trong xã hội Đông Nam A, nhất là việc gia tăng nghèo đói khu vục, hệ quả là nghèo đói gia tăng ở khu vục. Covid-19 có thể sẽ đẩy 36 triệu người ở Đông Nam Á vào tình trạng nghèo đói cùng cực. Với tình hình số ca nhiễm tiếp tục tăng từng ngày, cộng đồng ASEAN với gần 650 triệu dân đang chứng kiến số ca nhiễm tăng lên hàng ngày. Cuộc sống của người dân và nền kinh tế của cả khối ASEAN đang phải hứng chịu những ảnh hưởng nặng nề ngày một gia tăng. Tình hình đại dịch ở Đông Nam Á thể hiện một cục diện ảm đạm cho hơn 36 triệu người ở Đông Nam Á đang sống trong nghèo đói cùng cực (thu nhập dưới 1.90 USD mỗi ngày). Sự thiếu hụt $20 \%$ thu nhập do cuộc khủng hoảng hiện tại có thể đẩy 60 triệu người ở Đông Á và Thái Bình Dương vào tình trạng nghèo đói cùng cực và 160 triệu người khác tồn tại chật vật với ít hơn 3.2 USD mỗi ngày (Mercado, 2020). Tình hình tồi tệ nhất chủ yếu là đối với các quốc gia đang phát triển ở Đông Nam Á.

Cuộc khủng hoảng thậm chí sẽ tác động nghiêm trọng hơn đến những người đang phải vật lộn với nghèo đói, nhóm dễ bị tổn thương và phân biệt đối xử. Bởi lẽ, họ không những sẽ phải xoay sở khó khăn để được tiếp cận với dịch vụ y tế chất lượng tốt, mà nguy cơ khiến họ là 
nhóm đầu tiên hứng chịu những hệ quả của cuộc khủng hoảng kinh tế cũng lớn hơn.

Thứ ba, tác động về mặt chính trị - an ninh. Đại dịch COVID-19 đã làm leo thang cạnh tranh giữa Mỹ và Trung Quốc, đồng thời góp phần làm gia tăng căng thẳng trong quan hệ của Trung Quốc với Nhật Bản, Ấn Độ, Australia, EU. Trước những diễn biến đó, ASEAN dưới sự dẫn dắt của Việt Nam đã nhận ra các thách thức và cơ hội từ cạnh tranh các nước lớn tại khu vực, trong đó có vấn đề Biển Đông và tận dụng sự dịch chuyển trong chuỗi giá trị toàn cầu.

Trung Quốc gia tăng ảnh hưởng chính trị và an ninh, trong đó có vấn đề Biển Đông khi Mỹ và đồng minh đang phải vật lộn với việc đối phó với đại dịch Covid-19 và phục hồi kinh tế trong nước. Điều này đã khiến cho Biển Đông, rồi đến khu vực Mekong trở thành địa bàn tranh gianh quyết liệt giữa Mỹ và Trung Quốc, đặt $A S E A N$ và các quốc gia thành viên trong bối cảnh sức ép ngày càng lớn. Sự suy giảm về kinh tế ở Đông Nam Á sẽ tạo cho Trung Quốc động lực mới để mở rộng ảnh hưởng ở khu vực. Theo một số nhà phân tích, các khoản đầu tư của Bắc Kinh có thể sẽ được chào đón nhiều hơn trước đây, khi các chính phủ khu vực tìm cách phục hồi nền kinh tế của họ sau đại dịch Covid-19. Khi Mỹ và phương Tây gồng mình lên chống dịch trong nước, nhất là Mỹ sẽ tập trung cho cuộc bầu cử năm này, thì sẽ là cơ hội tốt để Trung Quốc vươn dài hơn bàn tay của minh ở khu vực.

Năm 2020, khi dịch bệnh lan tràn khắp thế giới và Trung Quốc được coi là đã thành công trong việc khống chế dịch bệnh và trên đà phục hồi phát triển kinh tế. Đây sẽ là cơ hội vàng cho Bắc Kinh thực hiện các ý đồ của mình ở Biển Đông. Đồng thời, Trung Quốc cũng khai thác sự mất tập trung hoặc dễ bị tổn thương của các quốc gia khác để mở rộng các yêu sách phi pháp của họ ở Biển Đông. Trung Quốc lợi dụng thế giới gồng mình chống chọi với đại dịch Covid-19, Trung Quốc các yêu sách hàng hải bất hợp pháp ở Biển Đông và có thể ít chịu sự chỉ trích của cộng đồng quốc tế. Hành động đâm chìm tàu cá của Việt Nam ở khu vực quần đảo Hoàng Sa vào ngày 02/04/2020 thể hiện rằng cho dù bất kỳ thiên tai dịch bệnh hay dịch bệnh virus corona đang diễn ra cũng sẽ ngăn họ đưa ra các tuyên bố khẳng định cái gọi là "chủ quyền” của mình.

Trung Quốc đang tranh thủ cơ hội, lợi dụng thời điểm quân đội Mỹ đang gồng mình chống dịch Covid-19 để nối lại các hoạt động quân sự trên biển Đông. Sự bùng phát Covid-19 làm giảm đáng kể khả năng triển khai tàu chiến của Hải quân Mỹ tại khu vực Châu Á-Thái Bình Dương. Trung Quốc có thể và sẽ hoạt động ở đó, trong khi Mỹ đang bị mắc kẹt. Những đợt rút lui tạm thời của Mỹ ở Biển Đông có thể tạo ra cơ hội để Trung Quốc có thể tận dụng. Đồng thời, Hải quân Mỹ hiện có 11 tàu sân bay trong biên chế. Song các tàu chạy bằng năng lượng hạt nhân đòi hỏi phải đại tu và bảo trì dài hạn, thường không có sẵn để triển khai ngay lập tức. Bênh cạnh đó, ngày 18/04/2020, Quốc vụ viện Trung Quốc đã phê chuẩn thành lập cái gọi là Khu Tây Sa và Khu Nam Sa thuộc "Thành phố Tam Sa” của tỉnh Hải Nam (Xinhuanet, 2020).

Trung Quốc triển khai loạt hoạt động gây hấn như điều tàu khảo sát địa chất Hải Dương 08 đi vào vùng đặc quyền kinh tế của Việt Nam rồi bám theo tàu khoan của Malaysia, cho tàu hải cảnh đâm chìm tàu cá của Việt Nam, tập trận trái phép ở quần đảo Hoàng Sa của Việt Nam. Trung Quốc diễn tập chống hạm trên Biển Đông, dường như nhằm đáp trả đợt diễn tập của hai tàu sân bay Mỹ. Theo đó, một lữ đoàn không quân hải quân trang bị cường kích JH-7 thuộc Bộ tư lệnh Chiến khu miền Nam, đóng quân tại đảo Hải Nam, đã diễn tập bắn đạn thật nhằm vào mục tiêu trên biển ngày 15 - 16/07/2020. Giới phân tích Trung Quốc cho rằng cuộc diễn tập chống hạm bằng máy bay này là động thái đáp trả các đợt diễn tập hiệp đồng của nhóm tác chiến tàu sân bay USS Nimitz và USS Ronald Reagan trên Biển Đông đầu tháng 02/2020.

Bên cạnh đó, Trung Quốc cũng tiếp tục đẩy mạnh hoàn thiện hoạt động cải tạo đảo và quân sự hoá tại Biển Đông. Trong những năm gần đây, Trung Quốc đã tăng cường sự hiện diện phi pháp tại Biển Đông, ngang nhiên bồi đắp các đảo nhân tạo, xây dựng các căn cứ quân sự, 
đường băng và triển khai trái phép tên lửa đất đối không. Hiện nay, Trung Quốc đang đẩy mạnh quân sự hóa các đảo thông qua việc triển khai thiết bị quân sự và xây dựng các cơ sở quân sự. Việc cải tạo mở rộng nhân tạo ở Biển Đông của Trung Quốc cũng như các hoạt động quân sự hoá của nước này sẽ tiếp tục được đẩy nhanh trong thời gian tới, không chỉ trong năm nay.

Nhằm ứng phó trước các hành động gia tăng ảnh hưởng của Trung Quốc ở khu vực Đông Nam Á, Mỹ và đồng minh thúc đẩy các hoạt động kiềm chế Trung Quốc ở khu vực, đặc biệt là trong vấn đề Biển Đông, gia tăng cường quan hệ song phương với minh và các đối tác then chốt ở khu vực. Cụ thể, ngày 04/07/2020, Hai nhóm tàu sân bay Mỹ Nimitz và Reagan cùng tiến hành đợt diễn tập chung đầu tiên sau nhiều năm trên Biển Đông, sau khi Mỹ bác bỏ hầu hết yêu sách chủ quyền của Trung Quốc tại khu vực, và cùng thời điểm hải quân Trung Quốc tập trận trái phép tại quần đảo Hoàng Sa thuộc chủ quyền Việt Nam. Đồng thời, cũng trong tháng 07/2020, Mỹ và các đồng minh trong nhóm "Bộ tứ kim cương" ở vùng Ân Độ Thái Bình Dương tổ chức đồng thời hai cuộc tập trận hải quân tại hai khu vực kế cận Biển Đông. Mỹ cũng tăng cường triển khai các tàu chiến tuần tra tự do hàng hải ở Biển Đông, điều chiến hạm áp sát nơi tàu khảo sát Địa chất Hải Dương 08 bị cáo buộc quấy nhiễu tàu khoan West Capella của Malaysia. Mỹ còn diễn tập hải quân chung với Australia, đồng thời yêu cầu Bắc Kinh ngừng hành vi bắt nạt láng giềng trong khu vực.

Căng thẳng giữa Trung Quốc và Mỹ được đẩy lên cao khi Mỹ đã phản ứng mạnh mẽ sau khi Trung Quốc bắn 02 tên lửa đạn đạo DF-26B và DF-21D (được xem là "sát thủ tàu sân bay") ra biển Đông vào ngày 26/08/2020 trong lúc tiến hành tập trận tại đây. Phía Mỹ cho rằng, các hành động của Trung Quốc, bao gồm thử tên lửa, càng khiến tình hình biển Đông thêm bất ổn. Một ngày sau vụ phóng, tàu khu trục mang tên lửa dẫn đường USS Mustin của Mỹ tuần tra gần quần đảo Hoàng Sa của Việt Nam (đang bị Trung Quốc chiếm giữ trái phép). Đáp lại, phát ngôn viên Bộ Quốc phòng Trung Quốc ngày 28/08/2020 chỉ trích Washington trở thành bên phá hoại và gây rối đối với hòa bình và ổn định ở biển Đông. Cùng ngày, Trung Quốc thông báo tiến hành cuộc tập trận kéo dài một tuần ở biển Bột Hải. Một cuộc tập trận khác của Bắc Kinh diễn ra ở Hoàng Hải từ ngày 29/08 đến 03/09/2020. Việc Trung Quốc tập trận cùng một lúc ở 04 vùng biển gồm Biển Đông, biển Hoa Đông, Hàng Hải và Vịnh Bột Hải được coi là hành động hiếm hoi có thể là để phát đi tín hiệu rằng Bắc Kinh sẵn sàng đối mặt với nguy cơ đối đầu với Mỹ và Đài Loan. Đồng thời, có thể Trung Quốc cũng muốn cho thế giới biết rằng nước này có năng lực huy động các lực lượng tại nhiều địa điểm khác nhau, dù Bắc Kinh không có ý định gây chiến với Mỹ.

Về mặt ngoại giao, trước các động thái của Trung Quốc làm gia tăng căng thẳng ở Biển Đông, Mỹ và đồng minh đã có những động thái mạnh mẽ nhằm kiềm chế Bắc Kinh. Mỹ đã tuyên bố các yêu sách chủ quyền của Trung Quốc ở Biển Đông là hành động "bất hợp pháp." Tuyên bố về Biển Đông ngày 13/07/2020 của Ngoại trưởng Mike Pompeo nêu lập trường của Mỹ về Biển Đông đã khẳng định: "Các tuyên bố chủ quyền của Trung Quốc với các nguồn tài nguyên ngoài khơi ở gần như toàn bộ Biển Đông là hoàn toàn bất hợp pháp, cũng như chiến dịch dọa nạt của họ nhằm kiểm soát chúng." Ngoại trưởng Mỹ Pompeo khẳng định chính sách của Trung Quốc với Biển Đông trong nhiều năm qua là "dùng biện pháp bắt nạt" để xâm phạm quyền chủ quyền của các nước quanh khu vực, nhằm thay thế luật quốc tế bằng tư duy "chân lý thuộc về kẻ mạnh." Washington cáo buộc Bắc Kinh "lợi dụng sự mất tập trung hoặc dễ bị tổn thương của các nước" do Covid-19 để mở rộng yêu sách bất hợp pháp ở Biển Đông. Đồng thời, Australia ngày 23/07/2020 cũng đệ trình công hàm lên Liên Hợp Quốc, khẳng định "không có cơ sở pháp lý đối với các yêu sách của Trung Quốc về lãnh thổ và hàng hải ở Biển Đông”, bác bỏ các yêu sách của Trung Quốc đối với quyền lịch sử, các quyền và lợi ích hàng hải được thiết lập trong "quá trình thực hiện lịch sử lâu dài ở Biển Đông." 
Mặt khác, Mỹ trừng phạt các công ty Trung Quốc hỗ trợ quân đội trong việc cải tạo đảo ở Biển Đông. Mỹ gần đây cũng đã thể hiện gia tăng các hình thức kiềm chế Trung Quốc tại Biển Đông qua việ ban bố lệnh trừng phạt các công ty Trung Quốc bị cáo buộc tiếp tay cho hoạt động xây dựng và quân sự hóa đảo nhân tạo phi pháp trên Biển Đông. Trước mắt, Washington đã tung đòn trừng phạt Bắc Kinh vì vấn đề biển Đông sau khi đưa một số cá nhân và 24 công ty vào danh sách đen. Cái tên nổi bật trong số này là Công ty Xây dựng truyền thông Trung Quốc (CCCC).

Bên cạnh Biển Đông thì khu vực Mekong giờ đây đã trở thành điểm nóng cạnh tranh chiến lược giữa Mỹ và Trung Quốc trong năm 2020. Động lực chính tạo ra xu hướng cạnh tranh này đó là chính sách đối ngoại ngày càng chủ động của Trung Quốc và sự gia tăng ảnh hưởng thông qua BRI và Hợp tác Mekong - Lan Thương (MLC) ở khu vực này. Trong khi đó, Mỹ đứng đầu trong cuộc cạnh tranh chiến lược này, nhất là trong khuôn khổ Ấn Độ Dương - Thái Bình Dương. Việc tái kích hoạt cơ chế LMI đã trở thành công cụ chính sách dành riêng cho tiểu vùng sông Mekong. Hành động của Mỹ đã thúc đẩy và tạo điều kiện thuận lợi cho các nước lớn khác tham gia can dự trong khu vực, cụ thể là Nhật Bản và Hàn Quốc. Đứng trước sự gia tăng cạnh tranh giữa các nước lớn ở khu vực tiểu vùng sông Mekong, các quốc gia trong khu vực cũng thu được nhiều lợi ích về mặt kinh tế và kỹ thuật, cũng như trong việc gia tăng khả năng lựa chọn để thúc đẩy sự phát triển kinh tế của mình. Tuy nhiên, việc duy trì thế cân bằng mong manh giữa các cường quốc, nhất là giữa Mỹ và Trung Quốc, là một thách thức. Nhiệmvụ nên trở nên khó khăn hơn khi mà cuộc đối đầu giữa Trung Quốc và Mỹ ngày càng trở nên gay gắt và quyết liệt hơn.

Sự gia tăng trọng cạnh tranh chiến lược Mỹ - Trung ở khu vực Đông Nam Á đã đặt ASEAN cũng như các quốc gia thành viên đứng trước sức ép phải chọn bên - điều mà ASEAN và các quốc gia trong khu vực không hề muốn. Theo đó, ngày 08/08/2020, bộ trưởng ngoại giao các nước ASEAN ra Tuyên bố chung về Tầm quan trọng của việc Duy trì hòa bình và ổn định ở khu vực Đông Nam Á. Tuyên bố mới thể hiện mối quan ngại gia tăng của ASEAN về việc khu vực trở thành sân khấu chính trong cạnh tranh Mỹ - Trung. Có thể thấy, ASEAN đã ra tuyên bố riêng về hoà bình và an ninh khu vực, ASEAN kiên quyết khẳng định lập trường "không chọn phe" dù áp lực cạnh tranh Mỹ - Trung gia tăng (Viet Anh, 2020). Trước đó, ngày 26/06/2020, Thủ tướng nước Chủ tịch ASEAN 2020 ông Nguyễn Xuân Phúc cũng đã khẳng định rằng: Trung Quốc và Mỹ là những đối tác quan trọng hàng đầu, cho nên, sự cạnh tranh sẽ ảnh hưởng đến toàn cầu và $A S E A N$, và "ASEAN luôn mong muốn một khu vực Châu Á - Thái Bình Dương hoà bình, ổn định, thịnh vượng, hợp tác cùng phát triển, và chắc chắc không muốn phải chọn bên nào mà chúng tôi hợp tác, phát triển cùng có lợi, vì hòa bình ở khu vực và sự phát triển tương lai của các đối tác, trong đó có Trung Quốc và Mỹ - những đối tác rất quan trọng ..." (Báo Chính phủ, 2020; Thanh Nam, 2020).

Thứ tư, ngoài nhũ̃ng thách thức đặt ra thì đại dịch Covid-19 lần này cũng là co hội để khu vục tăng cường sụ chuẩn bị cho khu vục và ứng phó với các mối nguy hiểm sức khỏe trong tuơng lai. Chẳng hạn như việc, ASEAN nên xem xét việc phát triển một kho dự trữ vật tư y tế trong khu vực; mở rộng phạm vi phòng thủ ASEAN về quản lý thảm họa, bao gồm hỗ trợ nhân đạo trong các trường hợp khẩn cấp về y tế; huy động các nguồn lực và xây dựng năng lực cho các quốc gia thành viên trong việc phát triển một chiến lược y tế công cộng dài hạn khả thi.

Bên cạnh đó, sự bùng phát đại dịch Covid-19 tại khu vực cũng gia tăng sức ép đối với các nước chuyển đổi kinh tế sang ứng dụng cộng nghệ thông tin mạnh mẽ hơn. Đại dịch Covid-19 buộc nhiều người trên thế giới, trong đó có Đông Nam Á, phải suy nghĩ lại về cuộc sống hàng ngày của chúng ta, từ nơi làm việc đến trường học, đến việc giải trí. Để đối phó với các lệnh cấm đi lại, đóng cửa trường học và các khuyến nghị không tập trung đông đúc và giữ khoảng cách khi xã giao để hạn chế sự lây lan của virus, nhiều người đã chuyển sang các công cụ số (online) để cố gắng tạo ra nhịp sống thường ngày. Điều không thể chối cãi là cần phải "số hóa" nơi làm việc 
và nơi học tập của chúng ta để có thể tiếp tục hoạt động hiệu quả. Những công ty, tổ chức có thể sử dụng công nghệ tốt nhất để tiếp tục hoạt động và từ đó, suy nghĩ lại về mô hình kinh doanh của họ cho tương lai bằng cách thúc đẩy nhanh chuyển đổi số và họ sẽ là những người đi trước đối thủ cạnh tranh trong thị trường. Đồng thời, đại dịch lần này cũng thúc đẩy dịch vụ y tế từ xa (Telehealth). Trước khi dịch Covid-19 bùng phát, đã có một số tiến bộ được thực hiện trong điều trị từ xa. Tuy nhiên, các quan chức y tế công cộng đang thúc đẩy các hệ thống chăm sóc sức khỏe mở rộng dịch vụ từ xa thông qua điện thoại thông minh và các công cụ khác. Mặt khác, đây cũng là cơ hội để thúc đẩy các nước chuyển đổi phát triern mô hình giáo dục trực tuyến, cũng như hội họp trực tuyến, ... Đây là những tác dụng mà đại dịch Covid-19 đem lại cho chúng ta.

Đồng thời, đại dịch Covid-19 cũng đã khuyến khích các thành viên ASEAN đẩy nhanh việc triển khai Cơ chế một cửa $\mathrm{ASEAN}$ và thông qua chứng nhận xuất xứ điện tử để khắc phục tình trạng gián đoạn trong thương mại do địa dịch Covid-19. Nghị định thư đầu tiên về sửa đổi Hiệp định thương mại hàng hoá ASEAN (ATIGA) có hiệu lực vào tháng 09/2020 chấp nhận chữ ký/con dấu điện tử. Từ tháng 11/2020, Hệ thống quá cảnh hải quan ASEAN (ACTS) liên quan đến Campuchia, Lào, Malaysia, Singapore, Thái Lan và Việt Nam được ra mắt, theo đó, các thương nhân có thể tiến hành vận chuyển qua các nước thành viên ASEAN tham gia hệ thống này chỉ với một xe tải một tờ khai hải quan và một giấy bảo lãnh của ngân hàng.

\section{Kết luận}

Có thể thấy, đại dịch Covid-19 là một phép thử tối quan trọng về khả năng phục hồi của ASEAN và khả năng thích ứng của ASEAN trong những biến đổi bất thường của tình hình thế giới và khu vực. Covid-19 đã tác động mạnh mẽ trên nhiều chiều kích khác nhau đối với tất cả các lĩnh vực của ASEAN trong nhăm 2020 và diễn biến và tác động của đại dịch Covid-19 đối với thế giới và khu vực vẫn còn dài ở phía trước, chúng ta vẫn chưa thể lường hết được. Tuy nhiên, những hệ quả trước mắt như trên thì chúng ta đã có thể nhìn thấy. Cho nên, các quốc gia không quyết liệt chống dịch và không có sự hợp tác hiệu quả với nhau thì khó có thể kiểm soát đại dịch trong thời gian tới. Cho nên, ASEAN cần một "tinh thần khu vực" trong việc ứng phó với những thách thức chung. Đại dịch Covid-19 giống như phép thử đối với tinh thần đoàn kết của ASEAN, cũng như tinh thần phối hợp nội khối hiện nay. Trong bối cảnh đại dịch bùng phát khắp thế giới hiện nay, thì ASEAN cũng đã nhanh chóng phát huy vai trò quan trọng của mình trong việc hợp tác quốc tế ở khu vực trong việc chống lại đại dịch và phục hồi kinh tế hiện nay cũng như hậu Covid-19.

\section{Tài liệu tham khảo}

Asian Development Bank (ADB). (2020). Asian development outlook update. Retrieved December 19, 2020, from https://www.adb.org/what-we-do/economicforecasts/september-

2020\#: :text=As\%20the\%20pandemic\%20persists \%2C\%20developing,contraction \%20 sin ce\%20the \%20early\%201960s.\&text=Growth\%20is\%20forecast\%20to\%20rebound,below $\% 20$ expectations\%20before\%20COVID\%2D19

Báo Chính phủ. (2020). Thủ tướng: ASEAN chắc chắn không muốn phải chọn bên nào [Prime Minister: ASEAN certainly does not want to choose which side]. Retrieved March 11, 2021, from Báo Điện Tử Chính phủ Nước Cộng hòa xã hội chủ nghĩa Việt Nam website: http://baochinhphu.vn/Chinh-tri-An-ninh/Thu-tuong-ASEAN-chac-chan-khong-muonphai-chon-ben-nao/399105.vgp

Lee, C., Negara, S. D., \& Sambodo, M. T. (2020). Covid-19's economic reckoning in Southeast Asia. Retrieved March 10, 2021, from https://www.iseas.edu.sg/wp- 
content/uploads/2020/09/ISEAS_Perspective_2020_107.pdf

Menon, J. (2020). Assessing the economic impacts of Covid-19 on ASEAN countries. Retrieved December 19, 2020, from East Asia Forum website: https://www.eastasiaforum.org/2020/03/27/assessing-the-economic-impacts-of-covid-19on-asean-countries/

Mercado, L. (2020). To tackle Covid-19, a united ASEAN must deliver urgently. Retrieved December 19, 2020, from The Jakarta Post website: https://www.thejakartapost.com/academia/2020/04/09/to-tackle-covid-19-a-united-aseanmust-deliver-urgently.html

Searight, A. (2020). The economic toll of Covid-19 on Southeast Asia: Recession looms as growth prospects dim. Retrieved April 19, 2020, from CSIS website: https://www.csis.org/analysis/economic-toll-covid-19-southeast-asia-recession-loomsgrowth-prospects-dim

Thanh Nam (2020). Thủ tướng Nguyễn Xuân Phúc trả lời báo chí về cạnh tranh Mỹ - Trung [Prime Minister Nguyen Xuan Phuc answered the press on US-China competition]. Retrieved March 10, 2021, from Vietnamnet website: https://vietnamnet.vn/vn/thoisu/chinh-tri/asean-khong-chon-ben-trong-canh-tranh-giua-my-trung-652098.html

Viet Anh (2020). ASEAN gửi thông điệp trước 'sức nóng' cạnh tranh Mỹ - Trung [ASEAN sends a message before the 'heat' of US-China competition]. Retrieved March 10, 2020, from Vnexpress website: https://vnexpress.net/asean-gui-thong-diep-truoc-suc-nong-canhtranh-my-trung-4144285.html

VNA. (2020). Covid-19 to force millions of Southeast Asian labourers to lose jobs. Retrieved April 19, 2020, from https://www.vir.com.vn/covid-19-to-force-millions-of-southeastasian-labourers-to-lose-jobs-75364.html

World Health Organization (WHO). (2020). Covid-19 coronavirus pandemic. Retrieved December 25, 2020, from Worldometers website: https://www.worldometers.info/coronavirus/

Xinhuanet. (2020). 国务院批准海南省三沙市设立市辖区 [The State Council approved the establishment of a municipal district in Sansha City, Hainan Province]. Retrieved April 19, 2020, from http://www.xinhuanet.com/local/2020-04/18/c_1125874572.htm 


\section{(c) (i) (5)}

Creative Commons Attribution-NonCommercial 4.0 International License. 